\title{
IMPACT OF PERFORMANCE MANAGEMENT PRACTICES ON BUSINESS PERFORMANCE - AN EMPIRICAL STUDY
}

\author{
Dr. Srijib Shankar Jha \\ Associate Professor, Department of Travel \& Tourism Management, Siliguri Institute of Technology, \\ Sukna, District: Darjeeling (W.B) Pin code: 734009
}

Article DOI: $\underline{\text { https://doi.org/10.36713/epra7952 }}$

DOI No: 10.36713/epra7952

\begin{abstract}
Several companies' efforts in recent years have been directed on techniques to strengthen people's commitment to the organization's overall success. Various authors have looked into the relationships between various aspects of HRM practise and their impact on employee competency. Similarly, while it is well known that performance management is linked to employee performance, little progress has been made in understanding the link between performance management and employee performance in the Indian context. The goal of this article is to determine the extent to which performance management framework variables are linked to employee perceptions and, in particular, business performance. In light of the data obtained from the literature research, a structured survey was completed for information collection from 200 employees in four organisations, which were measurably investigated. The findings show that the great majority of performance management components are favourably and essentially related to business performance.
\end{abstract}

KEYWORDS : performance management, retention, employee attitude, human resource management.

\section{INTRODUCTION}

In recent years, many organisations' efforts have been directed on techniques that strengthen people's commitment to the organization's overall success. 'Performance management' is the name given to this extremely important cycle. Performance management (PM) evolved from a combination of performance evaluations and performance estimating frameworks as a more complete sophisticated estimation and management framework. Organizational performance management frameworks were becoming increasingly complex, incorporating elements other than monetary indicators and focusing on the organization's long-term manageability. Since the mid-1990s, there has been a marked increase in both academic and practical research (Thorpe and Beasley, 2004; Neely, 1999) into the areas of authoritative performance estimation and management of both the organisation and the individual.

Performance management is a much broader and more complicated function of Human Resources, as it encompasses activities such as joint goal setting, continuous advancement surveys and regular correspondence, criticism and instruction for improved performance, the use of employee advancement programmes, and remunerating accomplishments. The performance management cycle begins when another officeholder joins a framework and ends when an employee leaves the organisation. Performance management can be thought of as a systematic cycle for enhancing an organization's overall performance through improving the performance of individuals within a group system. The following are key practises for performance management frameworks (PM framework): a clear set of working responsibilities; connecting employees to hierarchical objectives through clear performance desires, detailed in discernible and quantifiable terms; organising employee training and competency improvement; instructing rehearsals; regular performance assessment and evaluation (Murphy and Cleveland, 1996; Arvey and Murphy, 1998; DeNisi, 2000; Graham, 2004; Armstrong and Baron, 2004). Employee performance is checked and evaluated on a regular basis, and it is part of a larger technique of regular communication with employees. 


\section{THE TOURISM AND HOSPITALITY INDUSTRY}

The travel business, which is one of the largest in the world, and cordiality have long been important social activities for individuals. The desire to travel to different regions within one's own country or abroad in search of a change in climate and information can be traced back to ancient times. The travel industry is the sum total of the apparent multitude of wonders and connections arising from associations among sightseers, with governments and networks, businesses, and non-legislative organisations all involved in the process of attracting, transporting, facilitating, and dealing with these vacationers and other visitors. The travel business has experienced rapid growth and diversification in recent years, making it one of the world's fastest growing financial sectors. The travel industry now has a volume of business comparable to that of oil, food, and automobiles. The travel sector has grown to be one of the most important aspects of international trade, as well as one of the most important sources of income and business for several developing countries. The tourism industry's global expansion has resulted in economic and employment gains in a variety of fields, including development, agriculture, and telecommunications. Tourism is India's largest assistance business, accounting for 6.23 percent of the country's GDP and 8.78 percent of total employment. India receives more than 5 million foreign tourists each year and 562 million domestic visitors. Out of the USD 28.50 billion in unfamiliar trade in 2018, India's travel business generated roughly USD 28.50 billion. (Source: Statistics from the Ministry of Tourism, Government of India, 2018).

The future of the travel and hospitality industries in India is undeniably energising, but the industry faces a few HR challenges, including a lack of qualified staff at both operational and administrative levels, as well as a massive gap between flexibly side information sources and request side requirements. Apart from Human Resource Management practises, the vast majority of businesses require polished skill. For example, in the travel industry, low pay rates, long working hours, an ill-advised career path, a lack of expert development, a lack of training and advancement, and an inappropriate work-life balance are all common issues. Dealing with employee performance is one of the most challenging challenges that the travel industry and hospitality businesses face today, as it is entirely dependent on the employee's dedication, skill, and clarity of performance. It is widely accepted that if employees are successfully managed through a well-organized prize practise and input component, it can serve as a powerful tool for employee motivation and development.

\section{PROBLEM STATEMENT}

The need for solutions "on the best way to organise" and "what is typically noteworthy" in performance management mediations in the travel sector appears to be a significant research challenge. Furthermore, given the lack of evidence supporting the extent to which various components of performance management interact together to achieve business performance, the following two research topics appear to be relevant:

1. Do successful performance management rehearsals truly create the viewpoints and behaviours that are required for employees to achieve at their best?

2. What are the roadblocks to effective performance management execution?

The investigation is important for travel industry companies because it will show them how performance management may affect their business cycles and help them build a strong and stable business framework in India. The examination will aid in the understanding and recognition of elements that influence individual and hierarchical performance. The findings of the study will be used to identify convincing strategies for the travel industry association to use in order to reduce employee fatigue and promote cooperation, administration, inspiration, employee accountability, and performance.

\section{LITERATURE REVIEW}

Boselie et al. (2005) and Katou, and Budhwar (2006) claim that there are similarities as well as logical inconsistencies in performance management and performance research. Huselid (1995) used factor research to construct and approve lists of highcontribution performance management rehearses. He discovered that high-association performance management approaches are strongly and positively linked to various aspects of hierarchical performance, such as job connection, monetary performance, and profitability. Delaney and Huselid (1996) discovered that practises consistent with a high association performance management system, such as particularly specific personnel, incentive compensation, and preparation, were positively related to hierarchical performance. Follow-up observational studies have found logically robust, favourable links between a firm's usage of high-contribution performance management approaches and hierarchical performance (MacDuffie 1995; Delery and Doty 1996; Youndt, Snell, Dean and Lepak 1996; Huselid, Ichniowski et al. 1997; Katou and Budhwar 2007). 
Various researchers have looked into the links between specific HR practises and corporate financial performance. For example, Lam and White (1998) discovered that firms' HR strategies (measured by successful employee enlistment, above-average salary, and broad training and progression) were linked to return on resources, deal growth, and stock quality growth. Richard and Johnson (2001) looked at the impact of key performance management viability (evaluations of how well a variety of HR procedures were carried out) on various performance indicators using banks as an example. They discovered that key performance management adequacy was authentically linked to staff turnover, and that the link between this metric and profit for value was stronger among account managers with more capital power.

Preparing is significant in upgrading upper hand (Fairfield-Sonn, 1987), increasing nature of yield (Holzer et al., 1993), promoting hierarchical development, and improving productivity, according to studies revealing a favourable influence of preparing on company performance (Bartel, 1994). According to Kalleberg andMoody (1994), preparation appears to boost all aspects of company performance, including item type, advancement of items, employee relations, deal development, productivity, and piece of the pie. Preparation is also seen as a beneficial tool for adjusting to changes brought on by mechanical innovation, market competition, hierarchical organisation, and segment shifts (Knoke and Kalleberg, 1994). According to Russel, Terborg, and Powers (1985), there is a link between the use of business preparation programmes and financial performance. Performance evaluation helps to improve organisation tasks, increase proficiency (Alexander, 1989), eliminate defects (Youndt et al., 1996), improve item consistency and profitability (Alexander, 1989), and improve overall organisation performance (Casio, 1989; Redman et al., 1993). Four examination characteristics (recurrence of casual evaluations, use of target measures, use of emotional models, and use of evaluation results) were positively associated with company performance, according to Martell et al. (1996). Roberts (1995) found that a well-run, competent evaluation framework might significantly improve employee performance and firm benefit in a study of 3000 projects around the world. The use of performance evaluations (Borman 1991) and the linking of such evaluations to compensation has also been linked to increased business productivity (Gerhart and Milkovich 1990). Koch and McGrath (1996) found that companies that used more sophisticated staffing processes (such as arranging, enrolling, and selecting employees) had better job profitability. Impetus compensation contributes to increased item quality, more prominent acknowledgment of improvements, and enhanced firm success, according to connections between motivating force compensation frameworks and business performance (Hiltrop, 1996; Luthans, 1998). Over an 18-year period, Murphy (1985) examined the links between firm performance and motivator compensation of 461 chief executives in 72 firms, finding that leader compensation, including pay and reward as well as investment opportunities, stock property, and conceded compensation, was emphatically and positively associated with both investor returns and deal development.

The majority of the work on performance management and performance has been done in the United States, with the United Kingdom following suit in the last decade. The question that arises, however, is whether US and UK-based models, however appropriate they may be for the US, stand up in diverse environments. Various researchers from outside the United States have used this foundation to add to this writing in subsequent years. HR practises were linked to apparent hierarchy and market performance in both public and private enterprises in Israel, according to Harel and Tzafrir (1999). In their study of Korean enterprises, Lee and Miller (1999) found no evidence of a link between HR procedures and performance. In their examination of HR procedure in Pacific Rim countries, Bae, Chen, Wan, Lawler, and Walumba (2003) discovered that, when all was said and done, the impact of elite work frameworks worked adequately, but only under tremendously significant situations. Morishima (1998) found support for the possibility viewpoint in a Japanese organisation as an example. Ngo, Turban, Lau, and Lui (1998) investigated some work practises (preparation and compensation techniques) with high contributing qualities and discovered that they would increase authoritative performance in Hong Kong firms in general. Tsai (2006), a Taiwanese researcher, found that effective use of personnel strengthening exercises is linked to authoritative performance. With performance-based compensation, participatory dynamic, unregulated economy determination, and performance assessment, just elevated level employee responsibility was recognised as the key performance management result for improving performance in 74 Chinese SMEs, according to Zheng, Morrison, and O'Neill (2006).

\section{RESEARCH METHODOLOGY}

Probability sampling is employed in this research because under this sampling method, every thing in the universe has an equal chance of being included in the sample. Because the community from which the sample is collected does not consist of a homogeneous group, a predetermined sampling 
procedure is used to provide a representative sample. The population is divided into a few sub-populations known as strata, each of which is more homogeneous than the entire population, using defined sampling. Every association receives a comparable amount of samples from each strata, ensuring that every association receives a fair representation regardless of its size. Accordingly, a proportionate defined arbitrary sampling technique is being used to analyse 200 managers and chiefs of four travel firms in Kolkata, eastern India, namely Thomas Cook India Ltd., Kuoni India Ltd., Yatra.com, and Club 7 holidays. Employees in various positions from the aforementioned Indian travel businesses were polled to learn about their views and criticisms concerning performance management in relation to their performance. Equivalent percent respondents were chosen from all out managers and heads of an organisation to ensure a proportionate representation from each of the four chosen organisations. Furthermore, numerous strata or reaches were arranged based on employees' lengthy years of connection with that specific association, and a proportionate number of samples were haphazardly chosen from inside each strata. Given that the majority of the above-mentioned firms employ between 50 and 150 people, a reasonable number of respondents was chosen to represent the total number of employees and provide a substantial amount of data for analysis. The poll provided quantitative data, which was collected using a 5-point Likert scale reaction design. The verbal anchors changed from " $2=$ emphatically agree with the assertion" to "- 2 = firmly cannot help but dispute the assertion."

\section{VARIABLES}

Dependent Variable

\begin{tabular}{|l|ll|}
\hline \multicolumn{1}{|c|}{ Variable } & & \multicolumn{1}{c|}{ Description } \\
\hline $\begin{array}{l}\text { Business } \\
\text { performance }\end{array}$ & $\begin{array}{l}\text { Loyalty: The extent to which employees are committed to work for the company. } \\
\text { - }\end{array}$ & $\begin{array}{l}\text { Identification: The extent to which employees treat the company as if it were their own } \\
\text { and feel hopeful, motivated and enthusiastic about the company. }\end{array}$ \\
- & $\begin{array}{l}\text { Involvement: The extent to which employees are willing to exert considerable effort } \\
\text { and do their best to take the company forward. }\end{array}$ \\
\hline
\end{tabular}

Independent Variables

\begin{tabular}{|c|c|}
\hline Variables & Description \\
\hline Communication & $\begin{array}{l}\text { Awareness - tecnique: The degree to which the vision, strategy and the team's } \\
\text { purpose and contribution towards the strategy are communicated and understood. }\end{array}$ \\
\hline Responsibility & $\begin{array}{l}\text { Specific responsibilities: The extent to which performance requirements are clarified and } \\
\text { agreed on in terms of objectives, goals and measures which are fair, realistic and achievable }\end{array}$ \\
\hline Coaching & $\begin{array}{l}\text { Current: The degree to which skills requirements for current job effectiveness are specified, } \\
\text { development areas are agreed, and appropriate training / coaching are provided. } \\
\text { Future: The extent to which career plans exist and skills requirements for future job } \\
\text { requirements are developed. }\end{array}$ \\
\hline Resources & $\begin{array}{l}\text { Materials: The degree to which required resources are made available in terms of the } \\
\text { physical working environment and workspace. } \\
\text { Methods: The extent to which required resources are made available in terms of effective and } \\
\text { user-friendly operating systems, processes, job aids, procedure manuals, policies and } \\
\text { checklists. }\end{array}$ \\
\hline Feedback & $\begin{array}{l}\text { Feedback frequency: The extent to which feedback is frequent and regular on top of bi- } \\
\text { annual performance discussions } \\
\text { Feedback quality: The extent to which feedback is adequate, gives employees a chance to } \\
\text { explain difficulties, resolve problems and find ways to improve their performance. } \\
\text { Objectivity: The degree to which monitoring and evaluations of performance are fair and } \\
\text { based on facts. }\end{array}$ \\
\hline Reward & $\begin{array}{l}\text { Perceived link 'performance-reward': The degree to which employees believe that there is a } \\
\text { link between their contribution, reward and remuneration. } \\
\text { Recognition: The extent to which employees feel their efforts are recognized and supported. } \\
\text { Disciplinary approach: The extent to which employees perceive that poor } \\
\text { performance is dealt with. }\end{array}$ \\
\hline
\end{tabular}


ISSN (Online): 2455-3662

EPRA International Journal of Multidisciplinary Research (IJMR) - Peer Reviewed Journal

Volume: 7 | Issue: 7 | July 2021|| Journal DOI: 10.36713/epra2013 || SJIF Impact Factor 2021: 8.047|| ISI Value: 1.188

\section{HYPOTHESIS}

Positive linear relationships exist between the

resources, development, monitoring, and performance management practices (context, focus,

consequences) and business performance.

\section{DATA ANALYSIS}

Table 1

Correlations between variables

\begin{tabular}{|c|c|}
\hline \multicolumn{2}{|c|}{$\begin{array}{l}\text { Correlations } \\
\text { Marked correlations are significant at } \mathrm{p}<0.001 \\
\mathrm{~N}=200\end{array}$} \\
\hline & Business Performance \\
\hline Context & 0.53 \\
\hline Focus & 0.63 \\
\hline Resources & 0.50 \\
\hline Development & 0.63 \\
\hline Monitoring \& Feedback & 0.56 \\
\hline Consequence & 0.62 \\
\hline
\end{tabular}

As seen in Table 1, the results indicate that a substantial (moderate correlation coefficient of between 0.40 and 0.69 ) and significant ( $p<0.05$ ) relationship exists between all the performance management practices and business performance. Substantial positive correlations were reported between context and business performance $(\mathrm{r}=0.53$, $\mathrm{p}<0.05)$; focus and business performance $(\mathrm{r}=0.62 ; \mathrm{p}<$ $0.05)$; resources and business performance $(r=0.50$; $\mathrm{p}<0.05)$; development and business performance( $\mathrm{r}$ $=0.63, \mathrm{p}<0.05)$; feedback and business performance $(\mathrm{r}$ $=0.56, \mathrm{p}<0.05)$; and consequences and business performance $(r=0.63, \mathrm{p}<0.05)$. Hypothesis, stating that performance management practices have a positive effect on business performance has thus been substantiated.

\section{REGRESSION OF BUSINESS PERFORMANCE ON PERFORMANCE MANAGEMENT \\ PRACTICES}

As indicated in Table 2 business performance was significantly predicted by all six performance management practices, namely consequences $(\mathrm{t}=8.63$, $\mathrm{p}<0.001)$, development $(\mathrm{t}=6.71, \mathrm{p}<0.001)$, focus $(\mathrm{t}=5.61, \mathrm{p}<0.001)$, resources $(\mathrm{t}=4.49, \mathrm{p}<$ $0.001)$, context $(\mathrm{t}=2.89, \mathrm{p}<0.01)$, and monitoring and feedback $(\mathrm{t}=-2.01 ; \mathrm{p}<0.05)$.

Table 2

Regression of business performance on performance management practices

Regression Summary for Dependent Variable: Commit

$\mathrm{R}=.72419757 \mathrm{R}^{2}=.52446212$ Adjusted $\mathrm{R}^{2}=.52163435$

$\mathrm{F}(6,1009)=185.47 \mathrm{p}<0.0000$ Std.Error of estimate: 3.5896

\begin{tabular}{|l|l|l|l|l|l|l|}
\hline & \multicolumn{1}{|c|}{ Beta } & $\begin{array}{c}\text { Std. Err. Of } \\
\text { Beta }\end{array}$ & \multicolumn{1}{|c|}{ B } & Std. Err. Of B & t & p-level \\
\hline Intercept & & & 0.462942 & 0.289684 & 1.598091 & 0.110336 \\
\hline Context & 0.090636 & 0.031324 & 0.108496 & 0.037496 & 2.893544 & 0.003891 \\
\hline Focus & 0.213850 & 0.038087 & 0.154770 & 0.027565 & 5.614759 & 0.000000 \\
\hline Resources & 0.122648 & 0.027297 & 0.120924 & 0.026914 & 4.493047 & 0.000008 \\
\hline Development & 0.237253 & 0.035377 & 0.164332 & 0.024504 & 6.706449 & 0.000000 \\
\hline Mnt Fdback & -0.076187 & 0.037843 & -0.054942 & 0.027291 & -2.013226 & 0.044356 \\
\hline Consequence & 0.280670 & 0.032531 & 0.295873 & 0.034293 & 8.627890 & 0.000000 \\
\hline
\end{tabular}

Together the six performance management practices could account for $52.44 \%$ of the variance in business performance scores.

Based on the findings reflected in Table 2, Hypothesis, stating that performance management practices (context, focus, resources, development, monitoring and consequences) can be used to predict business performance has been substantiated. 


\section{CONCLUSIONS}

The major goal of this study was to investigate the relationship between performance management techniques and business success in the Indian travel industry, as well as the overall significance of the various strategies in achieving these outcomes. As a result, the hypotheses suggested by a hypothetical model have been considered through observation. This finding implies that leaders/managers who effectively provide employees with setting, reason and responsibility, advancement opportunities, resources, performance analysis, as well as results - as defined by Shirley (2005)'s High Performance Practices model will in general be associated with employees experiencing elevated levels of business performance.

Employees are more committed in workplaces where they can see the critical importance of their objectives in terms of the organization's planning and goal, receive significant levels of support in objective defining, see their objectives all things considered, and receive regular performance analysis, according to literature reviews and observational studies. In addition, this finding is consistent with the literature reviews, which suggests that employees are committed in a workplace where leaders/managers articulate a dream, encourage acknowledgment of achieving objectives, set superior goals, provide individualized help, and challenge employees to think about issues and work difficulties in new ways, all of which are activities incorporated in innovative leadership training. The findings also support the idea that employees are more committed in an environment where leaders/managers delegate or secure agreement on what should be done, monitor deviations from guidelines and take corrective action, and promise or truly reward employees in exchange for satisfactorily completing the task, which are all activities included in conditions.

\section{REFERENCES}

1. Amba-Rao, S.C., Petrick, J.A., Gupta, J.N.D., and Von der Embse, T.J. (2000), 'Comparative Performance Appraisal Practices and Management Values among Foreign and Domestic Firms in India,' International Journal of Human Resource Management, 11, 1, 60-89.

2. Amaratunga, D., \& Baldry, D. (2002). Moving from performance measurement to performance management. Facilities, 20 (5/6), 217-223.

3. Alexander, $F$ (1989). Performance appraisals. SmallBusiness Reports, 14(3), 20-29.

4. Bae, J., Chen, S., Wan, T.W.D., Lawler, J.J., and Walumba, F.O. (2003), 'Human Resource Strategy and Firm Performance in Pacific Rim Countries,' International Journal of Human Resource Management, 14, 8, 1308-1332.
5. Bartel, AP (1994). Productivity record from the implementation of employee training programs.

6. Becker, B.E. and Huselid, M.A. (1998), 'High performance work systems and firm performance: A synthesis of research and managerial implications.' In Personnel and Human Resource Management, v16, pp. 53-101.

7. Bhatnagar, J., and Sharma, A. (2005), 'The Indian Perspective of Strategic HR Roles and Organizational Learning Capability,' International Journal of Human Resource Management, 16, 9 , 1711-1739.

8. Borman, WC (1991). Job behavior, performance, and effectiveness. In Handbook of Industrial and Organizational Psychology, 2nd edition, $M D$ Dunnette and LM Hough (eds.). Palo Alto: CA Consulting Psychologists Press, 2271-1326.

9. BROWN, D. and ARMSTRONG, M. 1999. Paying for Contribution. Real Performance-related pay strategies. London: Kogan Page.

10. Budhwar, P., and Sparrow, P. (1998), 'National Factors Determining Indian and British PERFORMANCE MANAGEMENTPractices: An Empirical Study,' Management International Review, 38, Special Issue 2, 105-121.

11. Casio, WF (1989). Managing Human Resources, 2nd ed. New York: McGraw-Hill.

12. Chadwick, G., and Cappelli, P. (1998), 'Investments or Contracts? The Performance Effects of Human Resource Systems under Contingencies,' working paper, Wharton School, University of Pennsylvania, Philadelphia.

13. Delaney, J.T., and Huselid, M.A. (1996), 'The Impact of Human Resource Management Practices on Perceptions of Organizational Performance,' Academy of Management Journal, 39, 4, 949-969.

14. Delery, J and D Doty (1996). Mode of theorizing in strategic human resources management: Tests of universalistic, contingency, and configurational performance predictions. Academy of Management Journal, 39(4), 802-35.

15. Dyer, L and T Reeves (1995). Human resource strategies and firm performance: What do we know and where do we need to go? International Journal of Human Resource Management, 6(3), 656-670.

16. Fletcher, C. (2001). Performance appraisal and management: The developing research agenda. Journal of Occupational and Organisational Psychology, 74 (4), 473-488.

17. Fletcher, C., \& Williams, R. (1996). Performance Management, Job Satisfaction and Organisational Commitment. British Journal of Management, 7, 169-179.

18. FURNHAM, A. 2004. Performance managementSystems. European Business Journal. $83-94$.

19. Gerhart, B. (2005), 'Human Resources and Business Performance: Findings, Unanswered Questions and an Alternative Approach,' Management Revue, 16, 174-185. 
20. Gerhart, B and GI Milkovich (1992). Employee compensation: Research and practice. In Handbook of Industrial and Organizational Psychology, MD Dunnette and LM Hough (eds.). Palo Alto: Consulting Psychologists Press.

21. GOLEMAN, D. 1996. Emotional Intelligence. Why it can matter more than IQ. London: Bloomsbury Publishing.

22. Griliches, Zvi, "Introduction" in Zvi Griliches, ed., Output Measurement in the Service Sector, NBER Studies in Income and Wealth Volume 56, University of Chicago Press, 1992.

23. Harel, G.H., and Tzafrir, S.S. (1999), 'The Effect of Human Resource Management Practices on the Perceptions of Organizational and Market Performance of the Firm,' Human Resource Management, 38, 3, 185-200.

24. Hiltrop, SM (1996). The impact of human resource management on organizational performance: Theory and research. European Management Journal, 14(6), 628-637.

25. Ichniowski, C., Shaw, K., and Prennushi, G. (1997), 'The Effects of Human Resource Management Practices on Productivity: A Study of Steel Finishing Lines,' American Economic Review, 87, 3, 291-313.

26. Katou, A., and Budhwar, P. (2006), 'The Effect of Human Resource Management Systems on Organizational Performance: Test of a Mediating Model,' International Journal of Human Resource Management, 17, 7, 1223-1253.

27. Kalleberg, AL and JM Moody (1994). Human resource management and organizational performance. The American Behavioral, 37(7), 948-962. Luthans, $K \quad$ (1998). Using PERFORMANCE MANAGEMENTto compete in the 2lst century. Management Quarterly, 38(4), 1722.

28. KAPLAN, R.S. and NORTON, D.P. 1992. The Balanced Scorecard - measures that drive performance. Harvard Business Review. 70(1):7179.

29. KAPLAN, R.S. and NORTON, D.P. 1996. Linking the Balanced Scorecard to Strategy. Harvard: Harvard Business School Press.

30. Keep, E. and Mayhew, K. (1999) The Leisure Sector (Skills Task Force Research Paper 6), DfEE.

31. Khandwalla, P. (2002), 'Effective Organizational Response by Corporates to India's Liberalization and Globalization,' Asia Pacific Journal of Management, 19, 2/3, 423-448.

32. Koch, M.J., and McGrath, R.G. (1996), 'Improving Labor Productivity: Human Resource Management Policies Do Matter,' Strategic Management Journal, 17, 5, 335-354.

33. Kock, R., Roodt, G., \& Veldsman, T.H. (2002). The alignment between effective people management, business strategy and organisational performance in the banking and insurance sector. South African Journal of Industrial Psychology, 28 (3), 83-91.
34. Kotter, J.P., \& Heskett, J.L. (1992). Corporate culture and performance. New York: The Free Press.

35. Krishna, A., and Monappa, A. (1994), 'Economic Restructuring and Human Resource Management,' Indian Journal of Human Relations, 29, 490-501.

36. Lawler, J.J., Jain, H.C., Venkata Ratnam, C.S., and Atmiyanandana, V. (1995), 'Human Resource Management in Developing Economies: A Comparison of India and Thailand,' The International

37. Martell, $K$ and SJ Carroll (1995). Which executive human resource management practices for the top management team are associated with higher firm performance? Human Resource Management, 34(4), 497-512.

38. Murphy, KJ (1985). Corporate performance and managerial remuneration: An empirical analysis. Journal of Accounting and Economics, 7(1-3), 1142.

39. Morishima, M. (1998), 'Changes in Japanese Human Resource Management: Implications for Firm Performance,' paper presented at Workplace Conflict and Cooperation: Prospects for Employee Representation, University of Urbana-Champaign, 1-2 May.

40. NEELY, A., GREGORY, M. and PLATTS, K. 1995. Performance measurement system design. A literature review and research agenda. International Journal of Operations and Production Management. 15(4):80-116.

41. Ngo, H.-Y., Turban, D., Lau, C.-M., and Lui, S.-Y. (1998), 'Human Practices and Firm Performance of Multinational Corporations: Influences of Country of Origin,' International Journal of Human Resource Management, 9, 4, 632-652.

42. Paul, A.K., and Anantharaman, R.N. (2003), 'Impact of People Management Practices on Organizational Performance: Analysis of a Causal Model,' International Journal of Human Resource Management, 14, 7, 1246-1266.

43. Pratt, H.J. (1991). Principles of Effective Performance Management. Records Management Quarterly. Vol. 23 No.1. 28. - 33.

44. Richard, O.C., and Johnson, N.B. (2001), 'Strategic Human Resource Management Effectiveness and Firm Performance,' International Journal of Human Resource Management, 12, 2, 299-310.

45. Riley, M., Gore, J. and Kelliher, C. (2000) 'Economic determinism and human resource management practice in the hospitality and tourism industry', Tourism and Hospitality Research, 2(2), 118-128.

46. Russel, J.S., Terborg, J.R., and Powers, M.L. (1985), 'Organizational Performances and Organizational Level Training and Support,' Personnel Psychology, 38, 849-863.

47. Roberts, $K$ (1995). The proof of human resource is in the profits. People Management, 1(3), 42-43. 
48. Sangweni, S.S. (2003). Performance managementas a Leadership and Management Tool. Senior Management Services Conference.15 -17 June.

49. Schuler, R.S., and Jackson, S.E. (2005), 'A Quarter-century Review of Human Resource Management in the US: The Growth in Importance on the International Perspective,' Management Revue, 16, 11-35.

50. Singh, K. (2003), 'Strategic HR Orientation and Firm Performance in India,' International Journal of Human Resource Management, 14, 4, 530-543.

51. Som, A. (2006), 'Bracing MNC Competition Through Innovative PERFORMANCE MANAGEMENTpractices: The Way Forward for Indian Firms,' Thunderbird International Business Review, 48, 2, 207-237.

52. Spangenberg, H.H., \& Theron, C.C. (2001). Adapting the Systems Model of Performance Management to major changes in the external and internal organisational environments. South African Journal of Business Management, 32 (1), 35-47.

53. Stashevsky, S., \& Koslowsky, M. (2006). Leadership team cohesiveness and team performance. International Journal of Manpower, 27 (1), 63-74.

54. Steyn, A.G.W., Smit, C.F., Du Toit, S.H.C., \& Strasheim, C. (1995). Moderne Statistiek vir die Praktyk. Pretoria: Van Schaik Publishers.

55. Theron, C.C., \& Spangenberg, H.H. (2000). Confirmatory factor analysis of the performance management audit questionnaire. South African Journal of Psychology, 30 (4), 32-39.

56. THORPE, R. and BEASLEY, T. 2004. The characteristics of performance managementresearch. Implications and challenges. International Journal of Productivity and Performance Management. 53(4):334-344.

57. TOBIN, D.R. 1998. The knowledge-enabled organization. Moving from 'Training' to 'Learning' to Meet Business Goals. New York: Amacom.

58. Tsai, C.-J. (2006), 'High Performance Work Systems and Organizational Performance: An Empirical Study of Taiwan's Semiconductor Design Firms, ' International Journal of Human Resource Management, 17, 9, 1512-1530.

59. Tsui, A.S., Pearce, J.L., Porter, L.W. and Tripoli, A.M. (1997). 'Alternative approaches to the employee-organisation relationship: does investment in employees pay off?' In Academy of Management Journal, v40, pp. 1089-21.

60. Venkatraman, N., and Ramanujam, V. (1986), 'Measurement of Business Performance in Strategy Research: A Comparison of Approaches,' Academy of Management Review, 11, 801-814.

61. Van Dijk, \& H.C. Thornhill, C. (2003). Implementing Performance $M$ anagement to enhance Development. South Africa Journal of Public Administration. Vol.38. 464-467.

62. Williams, R.S. (2002). Managing Employee Performance. Design and Implementation in
63. Organisation.2nd ed. Singapore: Senge Lee Press.

64. Youndt, MA, SA Snell, JW Dean and DP Lepak (1996). Human resource management, manufacturing strategy, and firm performance. Academy of Management Journal, 39(4), 836-866.

65. Zheng, C., Morrison, M., and O'Neill, G. (2006), 'An Empirical Study of High Performance PERFORMANCE MANAGEMENT Practices in Chinese SMEs,' International Journal of Human Resource Management, 17, 10,1772-1803. 